\title{
Preparation, Characterization and Biological Study of New Boron Compound and Schiff Base Derived From 2-Aminophenol with Their Cu (II) and Pt (IV) Complexes
}

\author{
Asmaa Mohammed NooriKhaleel and MarwaIssaJaafar \\ University of Baghdad, College of Science, Chemistry Department, Baghdad, Iraq
}

\begin{abstract}
Two new ligands derived from 2-aminophenol have been prepared. The first ligand (boron compound) $L_{1}$ was prepared by refluxing one mole of sodium borohydride with two mole of 2-aminophenol in a mixture of methanol: acetone (2:1). The second ligand (Schiff base) $L_{2}$ was prepared by refluxing equimolar from 4-bromoacetophenone and 2-aminophenol in methanol: acetone (2:1). Cu (II) and Pt (IV) complexes of ligands have been also prepared. The ligands and their metal complexes were characterized by elemental analysis, molar conductivity and spectral studies of FTIR, ${ }^{1} \mathrm{H},{ }^{13} \mathrm{CNMR}$, thermal analysis, UV-VIS, as well as atomic absorption and magnetic susceptibility of metal complexes. All prepared compounds were tested as antibacterial agents against gram negative bacteria (E-coli)and gram positive bacteria (Staphylococcus aureus).
\end{abstract}

Keyword:2-aminophenol, boron compounds, Schiff bases.

\section{Introduction}

A large number of Schiff bases and their complexes have been studied for their interesting and important properties [1].The great interest in Schiff bases derived from 2-aminophenol is due to biological importance for having antidepressant, antimicrobial, antitumor, antiphlogogistic, nematocide, and other medicinal agents [2]. Many Schiff base ligands of 2-aminophenol have been synthesized by condensation of 2aminophenol with phthalaldehyde[3], thiazinediketon[4], salicylaldehyde[5],2,6-pyridinedicarboxaldehyde[6], terephthalaldehyde[7], pyrrol-2-carboxaldehyde[8], 4-aminoantipyrine[9], 1,4-diformyl benzen[10], 3phenylazo and thiazolylazopentadion[11], dicinnamoylmethan[12], 4-fluorophenyl-1-phenyl-pyrazol-4carboxaldehyde[13]. Boron is a natural product and occurs in the environment as borates [14]. Many natural products comprise boron isolated from bacteria, such as the antibiotic boromycin [15]. These natural products show that boron can be used in biological field without negative results for human health [16]. Boron compounds have unique physical and chemical properties such as low toxicity and thermal stability, therefor these compounds were used in a wide range of applications such as reagent materials, catalysts also used in medicine, radioactive metals, polymer science and supramolecular chemistry. The complexes of boron can be used for destroying diseased cell [17.18]. This paper reports the preparation and biological study of new two compounds derived from 2-aminophenol, the boron compound of 2-aminophenol andSchiff base of 2aminophenol with 4-bromoacetophenone as well as their copper (II) and platinum (IV) complexes. The biological activity for all prepared compounds were compared with starting materials.

\section{1- Materials, Instruments and Methods}

\section{Experimental}

All chemicals used were of analytical reagent grade. FTIR spectra were recorded on SHIMADZU 8400s spectrophotometer. Thermal analysis (TG and DTG) were carried out by using METTLER TA4000 SYSTEM .The electronic spectra $(190-1100 \mathrm{~nm}$ ) in DMSO were recorded on (SHIMADZU 1800-UV spectrophotometer). Elemental microanalysis were performed on (CHNS Elemental Analyzer CHNS-932). ${ }^{1} \mathrm{H}$ NMR and ${ }^{13} \mathrm{C}$ NMR were recorded on (Bruker NMR spectrometer $400 \mathrm{MHz}$ Avance III 400). The metal contents of the complexes were measured by atomic absorption technique using (Nov AA 350 spectrophotometer). Electrical conductivity measurements for complexes $\left(10^{-3} \mathrm{M}\right)$ in DMSO at room temperature were carried out by using Hunts Capacitor Trade Mark British made. The chloride content for complexes was determined by Mohr's method. Magnetic moments ( $\mu_{\text {eff. }}$ B.M) for the prepared complexes in the solid state at room temperature were measured by (Auto Magnetic Susceptibility Balance Model Sherwood Scientific).

\section{2-Synthesis of 2-boraneamino phenol $\left(\mathrm{L}_{1}\right)$.}

2-aminophenol $(0.2 \mathrm{~g}, 1.834 \mathrm{mmol})$ in a mixture of methanol:aceton $(2: 1)$ was mixed with a solution of sodiumborohydride $(0.034 \mathrm{~g}, 0.917 \mathrm{mmol})$ in $4.5 \mathrm{ml}$ of methanol. The reaction mixture was heated under reflux for $12 \mathrm{~h}$ under dry condition, evolved hydrogen gas was collected over water. The precipitation of the product 
took place after evaporating part of the solvent followed by addition of ether giving brown powder. The product was washedwith ether several times and dried in air.

\section{3-Synthesis of 2-((1-(4-bromophenyl)ethylidine)amino)phenol $\left(\mathbf{L}_{2}\right)$.}

A hot solution of 4-bromoacetophenon $(0.456 \mathrm{~g}, 1.83 \mathrm{mmol})$ in $6 \mathrm{ml}$ methanol was added to a hot solution of 2-aminophenol $(0.2 \mathrm{~g}, 1.83 \mathrm{mmol})$ in a mixture of methanol:aceton $(2: 1)$ with $1 \mathrm{ml}$ of glacial acetic acid as catalyst and the reaction mixture was heated under reflux for $16 \mathrm{~h}$. Precipitation of the product took place after evaporating part of the solvent followed by addition of ether giving golden brown precipitate. The product was washed several times with ether and dried in air.

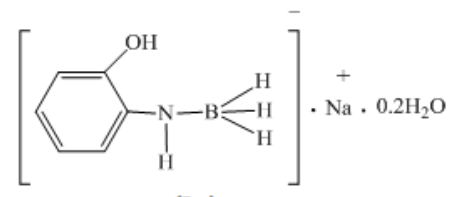

$\left(\mathrm{L}_{1}\right)$

2-boraneamino phenol

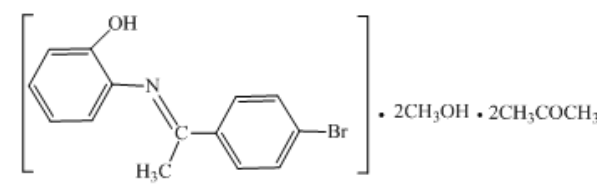

$\left(\mathrm{L}_{2}\right)$

2-((1-(4-bromophenyl)ethylidine)amino)phenol

Figure (1) : The structures of synthesized ligands $\mathrm{L}_{1}$ and $\mathrm{L}_{2}$.

\section{4-Synthesis of Copper Complexes $\mathrm{C}_{1}$ and $\mathrm{C}_{3}$}

$\mathrm{Cu}(\mathrm{II})$ complex $\mathrm{C}_{1}$ was prepared by adding a solution of $\mathrm{CuCl}_{2} .2 \mathrm{H}_{2} \mathrm{O}(0.0574 \mathrm{~g}, 0.3368 \mathrm{mmol})$ in $4 \mathrm{ml}$ methanol to a hot solution of $\mathrm{L}_{1}(0.1 \mathrm{~g}, 0.6737 \mathrm{mmol})$ in a mixture of methanol:aceton $(2: 1)$. The reaction mixture was heated under reflux for $4 \mathrm{~h}$. Part of solvent was evaporated and the dark brown product was obtained after addition of ether, washed several times with ether and dried in air.Cu(II) complex $\mathrm{C}_{3}$ was prepared by the same method mentioned in preparation of $\mathrm{C}_{1}$, using $\mathrm{L}_{2}(0.1 \mathrm{~g}, 0.2128 \mathrm{mmol})$ and $\mathrm{CuCl}_{2} .2 \mathrm{H}_{2} \mathrm{O}(0.0181 \mathrm{~g}, 0.1064 \mathrm{mmol})$.

\section{5-Synthesis of Platenium Complexes $\mathrm{C}_{2}$ and $\mathrm{C}_{4}$}

Platenium complexes were prepared by the same method mentioned in preparation of $\mathrm{C}_{1}$, using $0.1 \mathrm{~g}$ of $\mathrm{L}_{1}$ or $\mathrm{L}_{2}(0.6737$ and $0.2128 \mathrm{mmol})$ respectively with $\mathrm{K}_{2} \mathrm{PtCl}_{6}(0.1637 \mathrm{~g}, 0.3368 \mathrm{mmol})$ in $22 \mathrm{ml} \mathrm{DMSO}$ for $\mathrm{C}_{2}$ and $(0.0517 \mathrm{~g}, 0.1064 \mathrm{mmol})$ in $6 \mathrm{ml}$ DMSO for $\mathrm{C}_{4}$ respectively.

\section{Results And Discussion}

The physical and analytical data (Table 1) are agreement with suggested structures of studied compounds.

Table (1) :The physical properties and analytical data for two ligands and their metal complexes

\begin{tabular}{|c|c|c|c|c|c|c|c|c|}
\hline \multirow[t]{2}{*}{ Symbol } & \multirow[t]{2}{*}{ Color } & \multirow[t]{2}{*}{ Yield \% } & \multirow[t]{2}{*}{ m.p ${ }^{\circ} \mathbf{C}$} & \multicolumn{3}{|c|}{ CHN analysis Found(calc.) } & \multirow{2}{*}{$\begin{array}{l}\text { M\% } \\
\text { Found(calc.) }\end{array}$} & \multirow{2}{*}{$\begin{array}{l}\text { Cl\% } \\
\text { Found(calc.) }\end{array}$} \\
\hline & & & & $\mathrm{C} \%$ & $\mathrm{H} \%$ & $\mathbf{N \%}$ & & \\
\hline $\mathbf{L}_{1}$ & Brown & 70.2 & $>250$ & $\begin{array}{l}49.15 \\
(48.51)\end{array}$ & $\begin{array}{l}6.1 \\
(6.3)\end{array}$ & $\begin{array}{l}8.97 \\
(9.43)\end{array}$ & - & 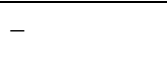 \\
\hline $\mathbf{L}_{2}$ & $\begin{array}{l}\text { Golden- } \\
\text { brown }\end{array}$ & 21.9 & $\begin{array}{l}\text { 134- } \\
137\end{array}$ & $\begin{array}{l}56.27 \\
(56.18)\end{array}$ & $\begin{array}{l}5.95 \\
(6.80) \\
\end{array}$ & $\begin{array}{l}4.34 \\
(2.97)\end{array}$ & - & - \\
\hline $\mathrm{C}_{1}$ & $\begin{array}{l}\text { Dark } \\
\text { brown }\end{array}$ & 79.3 & $>360$ & $\begin{array}{l}35.75 \\
(36.60) \\
\end{array}$ & \begin{tabular}{|l|l|}
5.13 \\
$(6.10)$ \\
\end{tabular} & $\begin{array}{l}5.21 \\
(4.27)\end{array}$ & - & $\begin{array}{l}9.62 \\
(10.86) \\
\end{array}$ \\
\hline $\mathrm{C}_{2}$ & $\begin{array}{l}\text { Dark } \\
\text { brown }\end{array}$ & 33 & $>360$ & $\begin{array}{l}37.85 \\
(37.28)\end{array}$ & $\begin{array}{l}4.81 \\
(4.94)\end{array}$ & $\begin{array}{l}6.56 \\
(5.93)\end{array}$ & $\begin{array}{l}27.48 \\
(27.55)\end{array}$ & $\begin{array}{l}3.2 \\
(5.01)\end{array}$ \\
\hline $\mathrm{C}_{3}$ & $\begin{array}{l}\text { Dark } \\
\text { brown }\end{array}$ & 48.3 & $>360$ & $\begin{array}{l}52.53 \\
(51.92)\end{array}$ & \begin{tabular}{|l|}
3.57 \\
$(3.70)$
\end{tabular} & \begin{tabular}{|l}
3.82 \\
$(4.32)$
\end{tabular} & $\begin{array}{l}10.88 \\
(9.87)\end{array}$ & $\begin{array}{l}2.6 \\
(2.7)\end{array}$ \\
\hline $\mathrm{C}_{4}$ & $\begin{array}{l}\text { Dark } \\
\text { brown }\end{array}$ & 39.2 & $>360$ & $\begin{array}{l}24.42 \\
(23.43)\end{array}$ & $\begin{array}{l}2.55 \\
(3.06)\end{array}$ & $\begin{array}{l}1.59 \\
(1.95)\end{array}$ & - & $\begin{array}{l}2.8 \\
(4.5)\end{array}$ \\
\hline
\end{tabular}

\section{1-IR spectra}

The FTIR spectra of ligands and their metal complexes were studied and the data are given in Table (2). The lattice and coordinated water were observed at (3420-3404) and $759 \mathrm{~cm}^{-1} \cdot{ }^{[19,20]}$ The spectra of the first ligand $\left(\mathrm{L}_{1}\right)$ (Figure 2) showed a strong band at $3400 \mathrm{~cm}^{-1}$ due to stretching vibration of O-H group, this band was shifted to the lower frequency in the spectrum of $\mathrm{C}_{1}$ complexat $3379 \mathrm{~cm}^{-1}$ as a result of complexation. ${ }^{[21]}$ The band appearedat $3377 \mathrm{~cm}^{-1}$ was attributed to stretching vibration of $\mathrm{N}-\mathrm{H}$ group for $\mathrm{L}_{1}$ and which absent in spectra of $\mathrm{C}_{1}$ and $\mathrm{C}_{2}$ complexes because of coordinate through the $\mathrm{N}$ atom. ${ }^{[2]}$ The spectra of $\mathrm{L}_{1}, \mathrm{C}_{1}$ and $\mathrm{C}_{2}$ showed bands at 2366, 2366 and $2363 \mathrm{~cm}^{-1}$ respectively, these bands assigned to vibrational mode of B-H. ${ }^{[23]}$ The spectrum of $\mathrm{L}_{1}$ exhibited the moderate band at $1454 \mathrm{~cm}^{-1}$ belong to $\mathrm{v}_{\mathrm{B}-\mathrm{N}}$, while this band was shifted to lower frequency at 1430 and $1417 \mathrm{~cm}^{-1}$ for $\mathrm{C}_{1}$ and $\mathrm{C}_{2}$ respectively. ${ }^{[23]}$ The strong band at $3448 \mathrm{~cm}^{-1}$ is due tovo${ }_{\mathrm{H}}$ (phenolic and methanolic) for $\mathrm{L}_{2}$ (Figure2), this band shifted to3400 $\mathrm{cm}^{-1}$ in $\mathrm{C}_{4}$ complex because of complexation ${ }^{[21,24]}$. The band appeared at $1581 \mathrm{~cm}^{-1}$ refer to stretching mode of $\mathrm{C}=\mathrm{N}$ in $\mathrm{L}_{2}$, this band change in 
profile and shifted to lower frequency at 1583 and $1577 \mathrm{~cm}^{-1}$ in $\mathrm{C}_{3}$ and $\mathrm{C}_{4}$ respectively as a result of coordinate $\mathrm{N}$ atom of $\mathrm{C}=\mathrm{N}$ with metal ions. ${ }^{[1,21,25]}$ Bands appeared at lower frequency due to stretching vibration of $\mathrm{M}-\mathrm{O}$, $\mathrm{M}-\mathrm{N}$ and $\mathrm{M}-\mathrm{Cl} .{ }^{[21]}$

Table (2):IRSpectra of two ligands and their metal complexes

\begin{tabular}{|l|l|l|l|l|l|l|l|l|l|}
\hline compound & vO-H & vN-H & vB-H & vB-N & vC=N & $\begin{array}{l}\text { H2O lattice } \\
\text { coordinate) }\end{array}$ & vM-O & vM-N & vM-Cl \\
\hline L1 & $\mathbf{3 4 0 0}$ & $\mathbf{3 3 7 7}$ & $\mathbf{2 3 6 6}$ & $\mathbf{1 4 5 4}$ & - & $\mathbf{3 4 1 7}$ & - & - & - \\
\hline C1 & $\mathbf{3 3 7 9}$ & - & $\mathbf{2 3 6 6}$ & $\mathbf{1 4 3 0}$ & - & $\mathbf{3 4 0 4 , 7 5 9 )}$ & $\mathbf{6 0 0}$ & $\mathbf{3 7 0}$ & $\mathbf{3 4 3}$ \\
\hline C2 & $\mathbf{3 4 0 4}$ & - & $\mathbf{2 3 6 3}$ & $\mathbf{1 4 1 7}$ & - & - & $\mathbf{5 3 0}$ & $\mathbf{3 4 1}$ & $\mathbf{2 7 3}$ \\
\hline L2 & $\mathbf{3 4 4 8}$ & - & - & - & $\mathbf{1 5 8 1}$ & - & - & - & - \\
\hline C3 & $\mathbf{3 4 4 0}$ & - & - & - & $\mathbf{1 5 8 3}$ & - & - & $\mathbf{3 8 7}$ & $\mathbf{3 1 2}$ \\
\hline C4 & $\mathbf{3 4 0 0}$ & - & - & - & $\mathbf{1 5 7 7}$ & $\mathbf{3 4 2 0}$ & $\mathbf{5 0 0}$ & $\mathbf{4 3 5}$ & $\mathbf{3 1 8 b r g}$ \\
\hline
\end{tabular}

Brg. $=$ bridging bond.

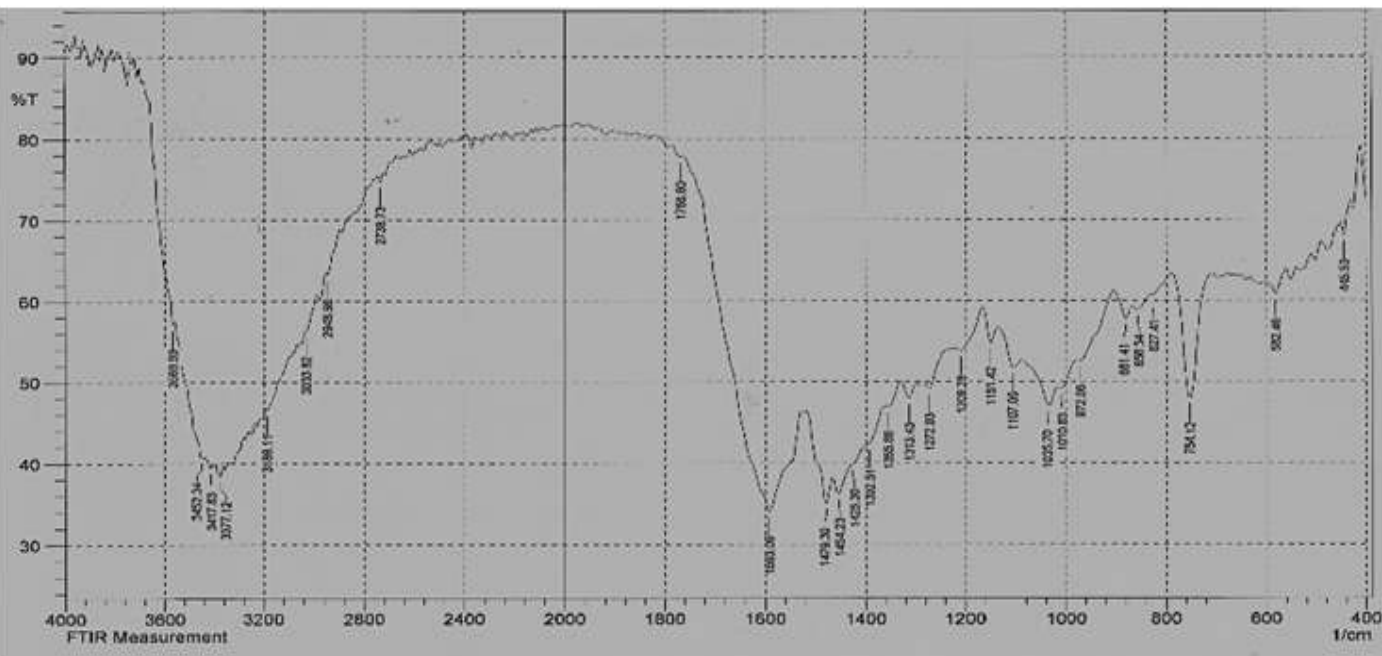

$\mathrm{L} 2$

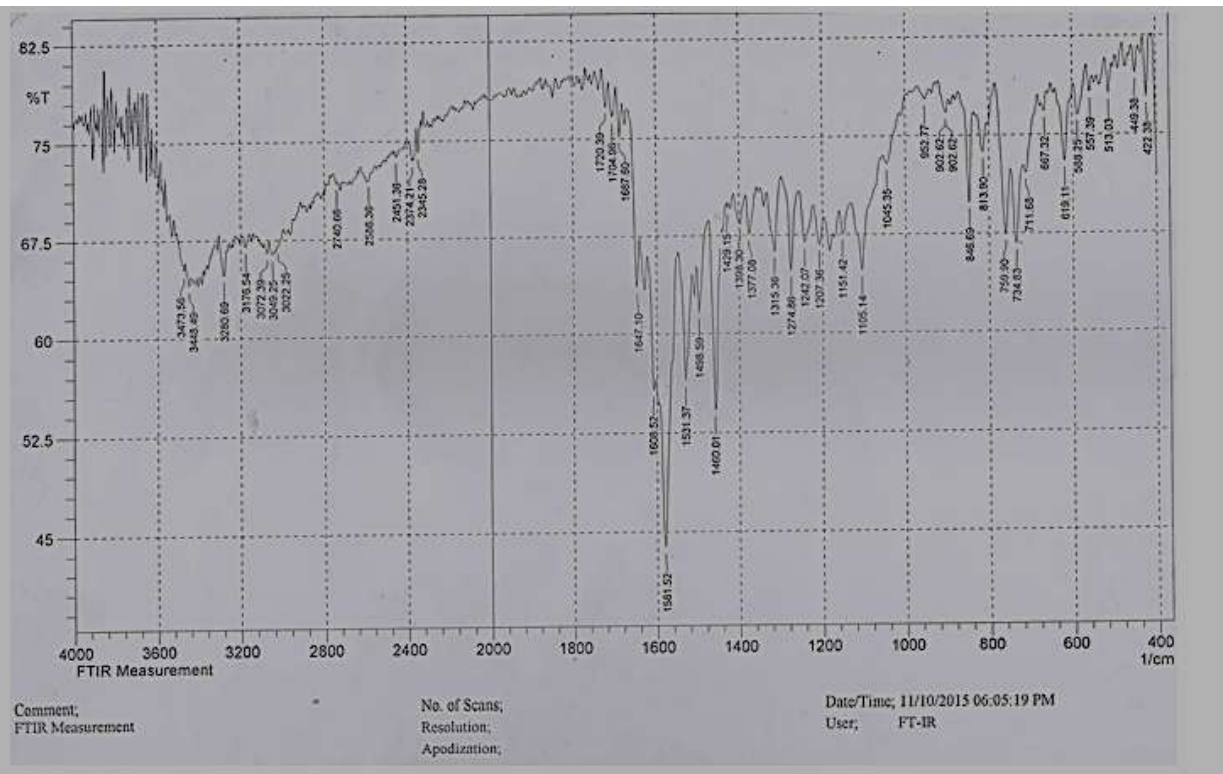

Figure (2):FTIR Spectra of $\mathrm{L}_{1}$ and $\mathrm{L}_{2}$. 


\section{2-Thermal Analysis}

The thermal stability of ligands were studied by TG and DTG analysis. The thermogram of $\mathrm{L}_{1}$ exhibited two steps at temperature range $\left(29.3-181^{\circ} \mathrm{C}\right)$ and $\left(181-774.7^{\circ} \mathrm{C}\right)$ with residue. Four steps appeared in thermogram of $\mathrm{L}_{2}$ at temperature range $\left(33.7-172.3^{\circ} \mathrm{C}\right),\left(172.3-280.7^{\circ} \mathrm{C}\right),\left(280.7-354.3^{\circ} \mathrm{C}\right)$ and $\left(354.3-601.3^{\circ} \mathrm{C}\right)$. The first step for each ligands involved loss of solvents and $\mathrm{H}_{2} \mathrm{O}$ and this due to their low boiling points ${ }^{[26,27]}$. The data (Table 3) showed the agreement between the theoretical and practical fragments and the results exhibited more stability of $\mathrm{L}_{1}$ than $\mathrm{L}_{2}$.

Table (3) : Thermal decomposition of $\mathrm{L}_{1}$ and $\mathrm{L}_{2}$.

\begin{tabular}{|c|c|c|c|}
\hline Compound & Steps & $\begin{array}{l}\text { Temp. range of } \\
\text { Decomposition }{ }^{\circ} \mathrm{C}\end{array}$ & $\begin{array}{l}\% \text { weight loss } \\
\text { Found (calc.) }\end{array}$ \\
\hline $\begin{array}{l}\mathrm{L}_{1} \\
\mathrm{C}_{6} \mathrm{H}_{9} \mathrm{NOB} . \mathrm{Na} .0 .2 \mathrm{H}_{2} \mathrm{O} \\
\mathrm{M.wt}=\mathbf{1 4 8 . 4 2}\end{array}$ & $\begin{array}{l}0.2 \mathrm{H}_{2} \mathrm{O} \\
\mathrm{OH} \\
4 \mathrm{H}\end{array}$ & 29.3-181.0 & 17.77 (16.57) \\
\hline & $\mathrm{C}_{6} \mathrm{H}_{4} \mathrm{~N}$ & 181-774.7 & $60.16(60.63)$ \\
\hline & $\mathrm{B}+\mathrm{Na}$ (residue) & - & $21.66(22.70)$ \\
\hline $\begin{aligned} & \mathrm{L}_{2} \\
& \mathrm{C}_{6} \mathrm{H}_{12} \mathrm{NOBr} .2 \mathrm{CH}_{3} \mathrm{OH} \\
& .2 \mathrm{CH}_{3} \mathrm{COCH}_{3} \\
& \text { M.wt }=469.9\end{aligned}$ & $\begin{array}{l}2 \mathrm{CH}_{3} \mathrm{OH} \\
2 \mathrm{CH}_{3} \mathrm{COCH}_{3} \\
8 \mathrm{H}\end{array}$ & 33.7-172.3 & $38.83(40.00)$ \\
\hline & $\mathrm{C}_{6} \mathrm{Br}+\mathrm{C}_{6}$ & 172.3-280.7 & 46.48 (47.64) \\
\hline & C & $280.7-354.3$ & $3.17(2.55)$ \\
\hline & $\mathrm{CH}_{3}+\mathrm{N}+\mathrm{OH}$ & 354.3-601.3 & $11.53(9.78)$ \\
\hline
\end{tabular}

\section{3- ${ }^{1}$ HNMR Analysis}

The peak assignments of ${ }^{1} \mathrm{HNMR}$ are described in Table (4). The ${ }^{1} \mathrm{HNMR}$ spectra of $\mathrm{L}_{1}$ and $\mathrm{L}_{2}$ in DMSO (Figure 3) exhibited broad and moderate multiplet signals of aromatic protons at $\delta(6.35-7.7 \mathrm{ppm}) .{ }^{[28]}$ The $\mathrm{OH}$ proton showed chemical shift at $\delta 8.5$ and $8.9 \mathrm{ppm}$ for $\mathrm{L}_{1}$ and $\mathrm{L}_{2}$ respectively. ${ }^{[24]}$ The spectrum of $\mathrm{L}_{1}$ showed broad peak appeared at $\delta 3.4 \mathrm{ppm}$ which was assigned to protons of $\mathrm{B}-\mathrm{H}$ and $\mathrm{H}_{2} \mathrm{O}$ as well as dissolved water in DMSO ${ }^{[23]}$. The chemical shift of amine proton was observed at $\delta 8.3 \mathrm{ppm}^{[29]}$. The spectrum of $\mathrm{L}_{2}$ exhibited peak at $\delta 1.9 \mathrm{ppm}$ which was assigned to protons of methyl group $\left(\mathrm{CH}_{3}\right.$ group and $\mathrm{CH}_{3}$ in acetone), While the proton of methyl group in methanol shifted to $\delta 3.3 \mathrm{ppm} \cdot{ }^{[30,31,32]}$ Also the dissolved water in DMSO was appeared at $\delta 3.3 \mathrm{ppm}^{[23]}$. A weak peak was observed at $\delta 4.3 \mathrm{ppm}$ which was assigned to proton of methanolicOH ${ }^{[30]}$. The strong peak at $\delta 2.5 \mathrm{ppm}$ was attributed to residual $\mathrm{DMSO}^{[23,30]}$.

Table (4): Chemical shifts for ${ }^{1} \mathrm{HNMR}$ of $\mathrm{L}_{1}$ and $\mathrm{L}_{2}$.

\begin{tabular}{|c|c|c|c|c|c|}
\hline \multicolumn{3}{|l|}{$\mathbf{L}_{1}$} & \multicolumn{3}{|l|}{$\mathbf{L}_{2}$} \\
\hline $\begin{array}{l}\text { Chemical shifts } \\
\delta(\mathrm{ppm})\end{array}$ & Mark & Assignments in DMSO & $\begin{array}{l}\text { Chemical shifts } \\
\delta(\text { ppm })\end{array}$ & Mark & Assignments in DMSO \\
\hline $3.4,3 \mathrm{H}, \mathrm{s}$ & 9,10 & $\begin{array}{l}\mathrm{B}-\mathrm{H}, \mathrm{H}_{2} \mathrm{O} \text { protons and } \\
\text { dissolved water in } \\
\text { DMSO }\end{array}$ & 1.9,9H,s & $8,16,18$ & $\begin{array}{l}\mathrm{CH}_{3} \text { protons and } \mathrm{CH}_{3} \\
\text { in acetone protons }\end{array}$ \\
\hline 6.35-7.7,4H,m & 3-6 & Aromatic protons & 3.3,3H,s & 15 & $\begin{array}{l}\text { Methanolic } \mathrm{CH}_{3} \\
\text { protons and dissolved } \\
\text { water in DMSO }\end{array}$ \\
\hline $8.3,1 \mathrm{H}, \mathrm{s}$ & 7 & N-H proton & $4.3,1 \mathrm{H}, \mathrm{s}$ & 15 & Methanolic $\mathrm{OH}$ proton \\
\hline $8.5,1 \mathrm{H}, \mathrm{s}$ & 2 & O-H proton & $6.35-6.63,8 H, m$ & $\begin{array}{l}3-6 \\
10,11,13,14\end{array}$ & Aromatic protons \\
\hline & & & $8.9,1 \mathrm{H}, \mathrm{s}$ & 2 & O-H proton \\
\hline
\end{tabular}

$\mathrm{S}=$ single, $\mathrm{m}=$ multiple 


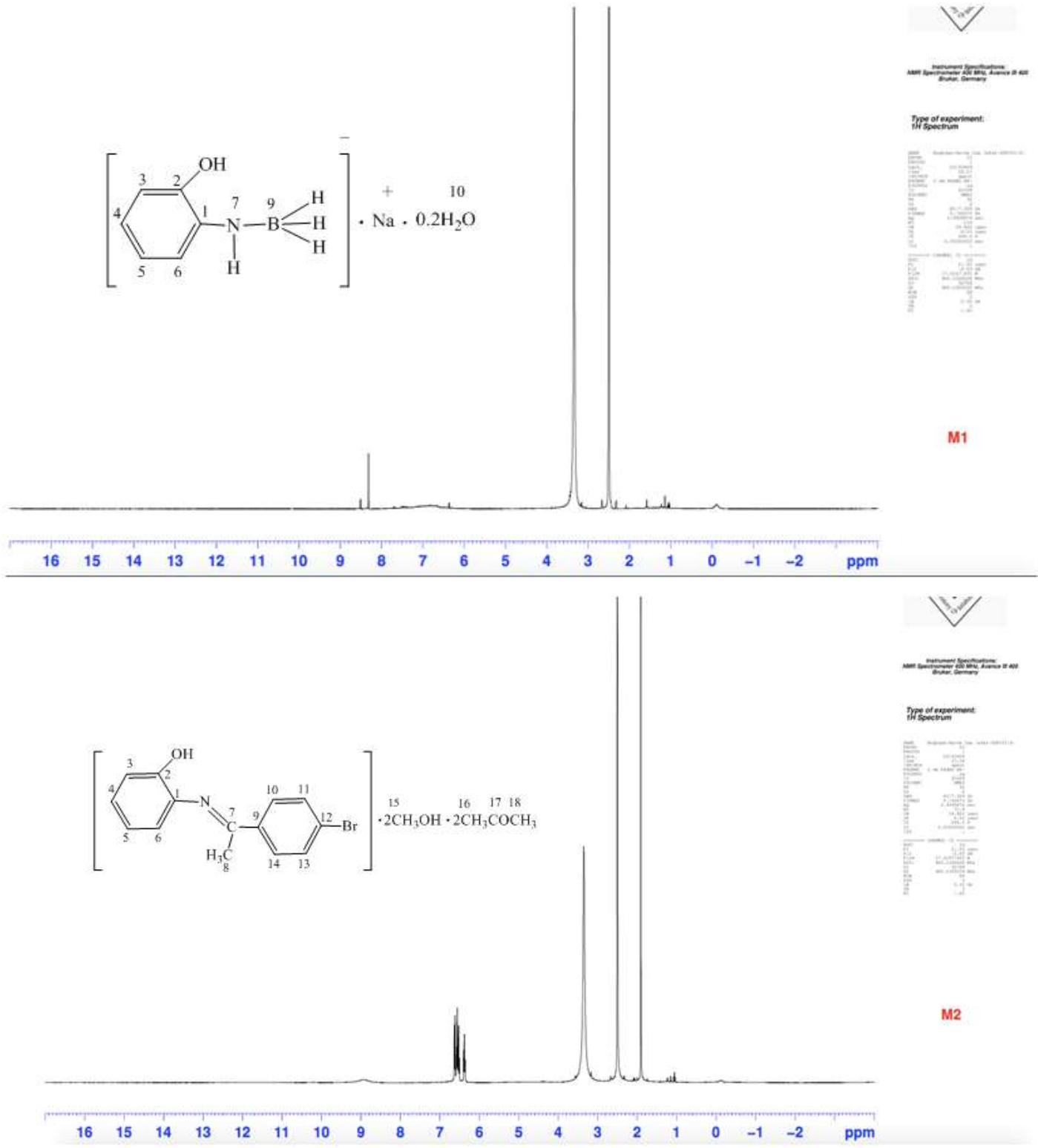

Figure (3) : ${ }^{1} \mathrm{HNMR}$ spectra of $\mathrm{L}_{1}$ and $\mathrm{L}_{2}$.

\section{4- ${ }^{13}$ CNMR Analysis}

The peak assignments of ${ }^{13} \mathrm{CNMR}$ are shown in Table (5). The ${ }^{13} \mathrm{CNMR}$ spectra of ligand $\mathrm{L}_{1}$ and $\mathrm{L}_{2}$ in DMSO showed resonance bands at $\delta(114.5-137.0 \mathrm{ppm})$ were assigned to aromatic carbon. ${ }^{[19]}$ The carbon atoms number 1 gave peaks at $\delta 125$ and $130.4 \mathrm{ppm}$ for $\mathrm{L}_{1}$ and $\mathrm{L}_{2}$ respectively, while the carbon atoms number 2 have been shifted to $\delta 145.5$ and $144 \mathrm{ppm}$ for $\mathrm{L}_{1}$ and $\mathrm{L}_{2}$ respectively. ${ }^{[30,33]}$ The $\mathrm{L}_{2}$ spectra showed chemical shift of methyl group at $\delta 20 \mathrm{ppm} .{ }^{[19]}$ The peak observed at $\delta 172 \mathrm{ppm}$ was assigned to azomethine carbon ${ }^{[19]}$. The carbon atom of methanol (C-O) was exhibited peak at $\delta 49 \mathrm{ppm}$, and the carbon atom in acetone $(\mathrm{C}=\mathrm{O})$ showed a peak at $\delta 204 \mathrm{ppm}^{[30]}$, while the carbon atoms number 16 and 18 were exhibited peak at $34 \mathrm{ppm}^{\left[{ }^{[30]} \mathrm{The}\right.}$ chemical shift of DMSO was appeared at $\delta 40 \mathrm{ppm} .^{[30]}$ 
Table (5): Chemical shifts (ppm) for ${ }^{13} \mathrm{CNMR}$ of $\mathrm{L}_{1}$ and $\mathrm{L}_{2}$

\begin{tabular}{|c|c|c|c|c|c|}
\hline \multicolumn{3}{|l|}{$\mathbf{L}_{1}$} & \multicolumn{3}{|l|}{$\mathbf{L}_{2}$} \\
\hline Chemical shifts $\delta(\mathrm{ppm})$ & Mark & AssignmentinDMSO & Chemical shifts $\delta(\mathrm{ppm})$ & Mark & Assignment in DMSO \\
\hline $127-137$ & $3-6$ & Aromatic carbons & 20 & 8 & Carbon of methyl group \\
\hline 125 & 1 & Carbon of amine & 34 & 16,18 & Carbon of acetone \\
\hline 145.5 & 2 & Carbon of phenol & 49 & 15 & Methanolic carbon \\
\hline & & & $114-125.2$ & $\begin{array}{l}3-6 \\
9-14\end{array}$ & Aromatic carbons \\
\hline & & & 130.4 & 1 & Carbon of amine \\
\hline & & & 136.3 & 12 & Carbon of brom \\
\hline & & & 144 & 2 & Phenolic carbon \\
\hline & & & 172 & 7 & Carbon of azomethine \\
\hline & & & 204 & 17 & Carbon of acetone \\
\hline
\end{tabular}

\section{5-Electronic spectra}

The spectral data of two ligands and their metal complexes in DMSO are given in Table (6). The spectra of $\mathrm{L}_{1}$ (Figure 4)and $\mathrm{L}_{2}$ exhibited high intensity bands at 33783 and $40650 \mathrm{~cm}^{-1}$ of $\mathrm{L}_{1}$ and $\mathrm{L}_{2}$ respectively, which were assigned to $\pi \rightarrow \pi^{*}$ transitions, in addition, low intensity bands appeared at 24390 and $23980 \mathrm{~cm}^{-1}$ of $\mathrm{L}_{1}$ and $\mathrm{L}_{2}$ respectively which were assigned to $\mathrm{n} \rightarrow \pi^{*}$ transitions. The spectra of $\mathrm{L}_{1}$ complexes exhibited bathochromic shift of ligand band to 39682 and $45454 \mathrm{~cm}^{-1}$ for $\mathrm{C}_{1}$ and $\mathrm{C}_{2}$ respectively, while the complexes of $\mathrm{L}_{2}$ showed hypsochromic shift of ligand band to 34482 and $39062 \mathrm{~cm}^{-1}$ for $\mathrm{C}_{3}$ and $\mathrm{C}_{4}$ respectively. The spectrum of $\mathrm{Cu}$ (II) complex $\mathrm{C}_{1}$ (Figure 4) showed absorption bands in the region around 15825 and $19801 \mathrm{~cm}^{-1}$ and were attributed to ${ }^{2} \mathrm{~B}_{1} \mathrm{~g} \rightarrow{ }^{2} \mathrm{~B}_{2} \mathrm{~g}\left(\mathrm{~V}_{1}\right)$ and ${ }^{2} \mathrm{~B}_{1} \mathrm{~g} \rightarrow{ }^{2} \mathrm{Eg}\left(\mathrm{V}_{2}\right)$ respectively of squar planer copper (II) complexes ${ }^{[19]}$. The magnetic moment of copper complex $\mathrm{C}_{1}$ was $\mu_{\text {eff. }}=1.74$ B.M and this value agree with squar planer geometry ${ }^{[19,22]}$. The band observed at $21190 \mathrm{~cm}^{-1}$ belong to charge transfer transition. The spectrum of copper complex $\mathrm{C}_{3}$ exhibited three bands at 15329,19794 and $20976 \mathrm{~cm}^{-1}$ and these bands were assigned to ${ }^{2} \mathrm{~B}_{1} \mathrm{~g} \rightarrow{ }^{2} \mathrm{~A}_{1} \mathrm{~g}$ $\left(v_{1}\right),{ }^{2} \mathrm{~B}_{1} \mathrm{~g} \rightarrow{ }^{2} \mathrm{~B}_{2} \mathrm{~g}\left(\mathrm{v}_{2}\right)$ and ${ }^{2} \mathrm{~B}_{1} \mathrm{~g} \rightarrow{ }^{2} \mathrm{Eg}\left(\mathrm{v}_{3}\right)$ transitions respectively of tetragonally distorted octahedral copper (II)complexes ${ }^{[19]}$. The magnetic moment of copper complex $\mathrm{C}_{3}$ was $\mu_{\text {eff. }}=2.4 \mathrm{~B}$.M and this value attributed to octahedral geometry ${ }^{[20]}$. The spectrum of diamagnetic platinum complex $\mathrm{C}_{2}$ exhibited bands at 19801 and 24103 which was belong to ${ }^{1} \mathrm{~A}_{1} \mathrm{~g} \rightarrow{ }^{3} \mathrm{~T}_{1} \mathrm{~g}(\mathrm{H})$ and ${ }^{1} \mathrm{~A}_{1} \mathrm{~g} \rightarrow{ }^{3} \mathrm{~T}_{2} \mathrm{~g}$ transition of octahedral geometry ${ }^{[34]}$. The spectrum of diamagnetic platinum complex $\mathrm{C}_{4}$ exhibited three bands at 12195, 22935 and $29614 \mathrm{~cm}^{-1}$ due to ${ }^{1} \mathrm{~A}_{1} \mathrm{~g} \rightarrow{ }^{3} \mathrm{~T}_{1} \mathrm{~g}(\mathrm{H})$ $\left(v_{1}\right),{ }^{1} \mathrm{~A}_{1} \mathrm{~g} \rightarrow{ }^{3} \mathrm{~T}_{2} \mathrm{~g}\left(\mathrm{v}_{2}\right)$ and ${ }^{1} \mathrm{~A}_{1} \mathrm{~g} \rightarrow{ }^{3} \mathrm{~T}_{1} \mathrm{~g}\left(\mathrm{v}_{3}\right)$ transitions respectively of octahedral $\mathrm{Pt}(\mathrm{IV})$ complex ${ }^{[34]}$. The conductivity measurements showed that all studied complexes were non electrolyte. ${ }^{[35]}$

Table (6): Electronic spectra, magnetic moment and molar conductance with suggested structures of $\mathrm{L}_{1}$ and $\mathrm{L}_{2}$

\begin{tabular}{|c|c|c|c|c|c|}
\hline symbol & $\begin{array}{l}\text { Band position } \\
\mathrm{cm}^{-1}\end{array}$ & Assignments & $\begin{array}{l}\mu_{\text {eff. }} \\
\text { B.M }\end{array}$ & $\begin{array}{l}\text { MolarConductivity } \\
\text { S.mol }^{-1} . \mathrm{cm}^{-1}\end{array}$ & $\begin{array}{l}\text { Suggested } \\
\text { structures }\end{array}$ \\
\hline $\begin{array}{l}\mathrm{C}_{1} \\
\mathrm{Cu}(\mathrm{II})\end{array}$ & $\begin{array}{ll}v_{1} & 15825 \\
v_{2} & 19801 \\
v_{3} & 21190\end{array}$ & $\begin{array}{l}{ }^{2} \mathbf{B}_{1} \mathbf{g} \rightarrow{ }^{2} \mathbf{B}_{2} \mathbf{g} \\
{ }^{2} \mathbf{B}_{1} \mathbf{g} \rightarrow{ }^{2} \mathbf{E g} \\
\mathbf{L} \rightarrow \mathbf{M}(\mathbf{C} . \mathbf{T})\end{array}$ & 1.74 & 0.0681 & Squar planer \\
\hline $\begin{array}{l}\mathrm{C}_{2} \\
\operatorname{Pt}(\mathrm{IV})\end{array}$ & \begin{tabular}{ll|}
$v_{1}$ & 19801 \\
$v_{2}$ & 24103 \\
\end{tabular} & $\begin{array}{l}{ }^{1} A_{1} g \rightarrow{ }^{3} T_{1} g(H) \\
{ }^{1} A_{1} g \rightarrow{ }^{3} T_{2} g\end{array}$ & diamagnetic & 0.1077 & octahedral \\
\hline $\begin{array}{l}\mathrm{C}_{3} \\
\mathrm{Cu}(\mathrm{II})\end{array}$ & $\begin{array}{ll}v_{1} & 15329 \\
v_{2} & 19794 \\
v_{3} & 20976\end{array}$ & $\begin{array}{l}{ }^{2} \mathbf{B}_{1} \mathbf{g} \rightarrow{ }^{2} \mathbf{A}_{1} \mathbf{g} \\
{ }^{2} \mathbf{B}_{1} \mathbf{g} \rightarrow{ }^{2} \mathbf{B}_{2} \mathbf{g} \\
\mathbf{L} \rightarrow \mathbf{M}(\mathbf{C} . \mathbf{T})\end{array}$ & 2.4 & 0.0337 & $\begin{array}{l}\text { distorted } \\
\text { octahedral }\end{array}$ \\
\hline $\begin{array}{l}\mathrm{C}_{4} \\
\mathrm{Pt}(\mathrm{IV})\end{array}$ & \begin{tabular}{ll|}
$v_{1}$ & 12195 \\
$v_{2}$ & 22935 \\
$v_{3}$ & 29614
\end{tabular} & $\begin{array}{l}{ }^{1} \mathbf{A}_{1} g \rightarrow{ }^{3} T_{1} g(H) \\
{ }^{1} A_{1} g \rightarrow{ }^{3} T_{2} g \\
{ }^{1} A_{1} g \rightarrow{ }^{3} T_{1} g\end{array}$ & diamagnetic & 0.0591 & octahedral \\
\hline
\end{tabular}

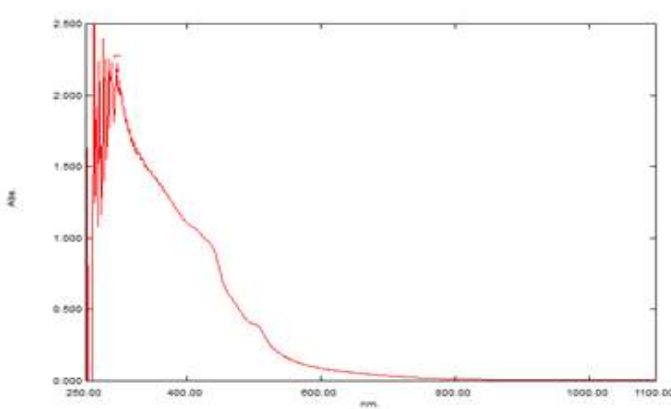

$\left(\mathrm{L}_{1}\right)$

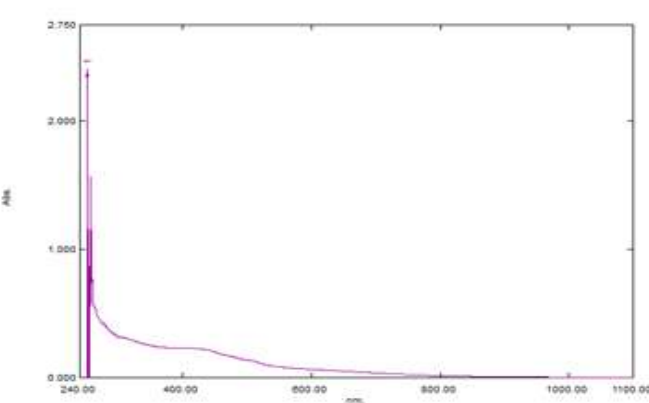

$\left(\mathrm{C}_{1}\right)$

Figure (4): UV-VIS spectra of $\mathrm{L}_{1}$ and its copper complex $\mathrm{C}_{1}$. 


\section{6- Antibacterial Activity}

Screening for antibacterial activity of all studied compounds and starting materials were tested against $\mathrm{G}-\mathrm{ve}$ bacteria (E-Coli) and $\mathrm{G}+\mathrm{ve}$ bacteria (Staphylococcus aureus) by agar diffusion method using $1 \times 10^{-2} \mathrm{M}$ of studied compounds in DMSO. The obtained data Table(7) showed that all compounds were in active against $E$ Coli, while these compounds exhibited different activities against Staphylococcus aureus except 4bromoacetophenon and sodium borohydride were in active. The antibacterial activity of studied compounds were compared with antibiotics cephalexim and cefatoxim.

Table (7): Antibacterial activity of two ligands and their metal complexes.

\begin{tabular}{|l|l|l|}
\hline Compounds & Staphylococcus aureus diameter $\mathbf{~ m m}$ & E-Coli diameter $\mathbf{~ m m}$ \\
\hline DMSO & zero & zero \\
\hline 2-aminophenol & 36 & zero \\
\hline 4-bromoacetophenone & zero & zero \\
\hline Sodium borohydride & zero & zero \\
\hline $\mathrm{L}_{1}$ & 28 & zero \\
\hline $\mathrm{L}_{2}$ & 25 & zero \\
\hline $\mathrm{C}_{1}$ & 23 & zero \\
\hline $\mathrm{C}_{2}$ & 20 & zero \\
\hline $\mathrm{C}_{3}$ & 32 & zero \\
\hline $\mathrm{C}_{4}$ & 20 & zero \\
\hline $\mathrm{Cephalexim}_{\text {Cefatoxim }}^{25}$ & zero \\
\hline
\end{tabular}

Figure (5) : suggested structures of the prepared complexes.

\section{References}

[1]. G.G.Mohamed, M.M.Omar, A.H.Hindy, "Metal Complexes of Schiff Bases :Preparation, Characterization, and Biological activity", Turk J.Chem, 30,361-382(2006).

[2]. E.Akila, M.Usharani, R.Rajavel, "A review- general applications of Schiff base transition metal complexes derived from 2aminophenol", International Journal of Advance Scientific and Technical Research, 5(3),457-469(2013). 
[3]. S.M.Abdallah, G.G.Mohamed, M.A.Zayed, M.S.A.El-Ela, "Spectroscopic study of molecular structures of novel Schiff base derived from O-phthalaldehyde and 2-aminophenol and its coordination compounds together with their biological activity", SpectroChemicaActa part A, 73,833-840(2009).

[4]. O.M.I.Adly, "Characterization, molecular modeling and antimicrobial activity of metal complexes of tridentate Schiff base derived from 5-acetyl-4-hydroxy-2H-1,3-thiazine-2,6-(3H)-dione and 2-aminophenol", SpectroChemicaacta part A: molecular and biomolecular Spectroscopy, 95, 483-490(2012).

[5]. A.A.Abdel Aziz, A.N.M.Salem, M.A.Sayed, M.M.Aboaly,"Synthesis, Strectural Characterization, Thermal studies, Catalytic efficiency and antimicrobial activity of some M(II) Complexes with ONO tridentate Schiff base N-salicylidene-Oaminophenol( $\left.\mathrm{saphH}_{2}\right)$ ", Journal of Molecular Structure, 1010, 130-138(2012).

[6]. G.G.Mohamed, Z.H.Abd El-Waha, "Mixed ligand complexes of bis(phenylimine) Schiff base ligands incorporating pyridenium moiety Synthesis, Characterization and antibacterial activity", SpectroChamicaActa part A, 61, 1059-1068(2005).

[7]. R.Pallikkavill, M.B.Ummathur, K.Krishnankutty, " Schiff bases of Terephthalaldehyde with 2-aminophenol and 2-aminothiophenol and their metal complexes", Archives of Applied Science Research , 4, 2223-2227(2012).

[8]. B.K.Singh, A.Prakash, H.K.Rajour, N.Bhojak, D.Adhikari, " Spectroscopic characterization and biological activity of Zn(II), Cd(II), $\mathrm{Sn}(\mathrm{II})$ and $\mathrm{Pb}$ (II) complexes with Schiff base derived from pyrrol-2-carboxaldehyde and 2-aminophenol", SpectroChemicaActa part A, 76, 376-383(2010)

[9]. G.G.Mohamed, M.M.Omar, A.A.Ibrahim, " Biological activity studies on metal complexes of novel tridentate Schiff base ligand Spectroscopic and thermal characterization", European Journal of Medicinal Chemistry, 44, 4801-4812(2009).

[10]. 10-S.Arunachalam,N.P.priya,C.Jayabalakrishnan,V.Chinnusamy,"Synthesis,Spectral characterization, Catalytic and antibacterial studies of new Ru(III) Schiff base complexes containing chloride/bromide and triphenylphosphine/arsine as co-ligand", SpectroChemicaActa part A, 74, 591-596(2009).

[11]. K.Krishnankutty, P.Sayudevi, M.B.Ummathur," Metal complexes of Schiff bases derived from 3-(arylazo)-2,4-pentanedions with 2aminophenol and 2-aminothiophenol", J.Serb.Chem.Soc., 72, 1075-1084(2007).

[12]. K.Krishnankutty, M.B.Ummathur, P.Sayudevi," Metal complexes of Schiff bases Derived From Dicinnamoyl methane And Aromatic Amines", The Journal of the Argentine Chemical Society, 96, 13-21(2008).

[13]. A.Sharma, T.Mehta, M.K.Shah," Synthesis and spectral studies of transition metal complexes supported by NO-bidentate SchiffBase ligand", Der ChemicaSinica, Pelagia Research Library, 4, 141-146(2013).

[14]. M.Kabu, M.S.Akosman," Biological Effect of Boron", Springer, 225, 57-75(2013).

[15]. W.G.Woods," An Introduction to Boron : History, Sources, Uses and Chemistry", Office of Environmental Health and Safety, 102, 5-11(1994).

[16]. O.Gozhina,"Design,Synthesisand Biological Activity of $\quad$ Small $\quad \alpha$-Aminoboron $\quad$ Containing Peptidomimetics",Ph.D.desertation,University of Tromso(2013).

[17]. Y.Zhu, X.Siwei, J.A.Maguire,N.S.Hosmane," Review-Application of Cycloaddition Reactions to the Synthesis of Novel Boron compounds", Molecules, 15, 9437-9449(2010).

[18]. A.Olejniczak," Medical applications of boron compounds-Boron Targets Cancer", Research in progress organic chemistry, 3, 3637(2007).

[19]. A.J.Abdulghani, A.M.N.Khaleel," Preparation and Characterization of Di,Tri., and Tetranuclear Schiff base complexes Derived from Diamines and 3,4-Dihydroxybenzaldehyde", Bioinorganic chemistry and applications, 1-14(2013).

[20]. A.M.N.Khaleel," Synthesis and Characterization of new Schiff bases and amides derived from N(1) substituted isatine with 2aminobenzothiazole, 2-aminopyridine and di thiooxamide and some of their metal complexes", Ph.D.Thesis, University of Baghdad(2008).

[21]. A.J.Abdulghani, A.M.N.Khaleel," Synthesis and Characterization of New Schiff Bases Derived from N(1)-Substituted Isatine with Dithiooxammide and Their Co(II), Ni(II), Cu(II), Pd(II), and Pt(IV) Complexes", Bioinorganic Chemistry and applications, 1 12(2009).

[22]. Lutfullah, A.Umar, M.M.Rahman, M.M.Khan, Y.B.Hahn," Synthesis and Physico-Chemical and Spectroscopic Investigations of Sodium Dihydrobis(1,2,3-benzotriazolyl)borate Ligand and its Transition Metal Complexes", Turk J.Chem, 31, 179-189(2007).

[23]. A.M.N.Khaleel," Synthesis and Characterization of Trihydro mono and Dihydrobis(indole-3-acetic acid)Borate Ligands and Some of Their Metal Complexes", Iraqi Journal of Science, 56, 4A, 2762-2772(2015).

[24]. K.A.shaikh, K.Shaikh," Synthesis,spectralcharacterization,thermal properties and DNA cleavage studies of series of Co(II),Ni(II) and $\mathrm{Cu}(\mathrm{II})$ polypyridine complexes with some new Schiff-bases derived from 2-chloroethylamine", Canadian Chemical Transactions,3(2),207-224(2015).

[25]. A.Xavier, N.Srividhya," Synthesis and Study of Schiff base Ligands", IOSR Journal of Applied Chemistry(IOSR-JAC), 7, 615(2014).

[26]. O.Sahin,A.N.Bulutcu," Evaluation of Thermal Decomposition Kinetics of Borax Pentahydrate Using Genetic Algorithm Method by Isothermal Analysis", Turk.J.Chem,27,197-207(2003).

[27]. A.Magda, R.Pode, C.Muntean, M.Medeleanu, A.Popa," Synthesis and characterization of ammonium phosphate fertilizers with boron", J.Serb.Chem.Soc.,75(7),951-963(2010).

[28]. N.K.Chaudhary,"Invitro antibacterial studies of some transition metal complexes of Schiff base derived from 2-aminophenol and furan-2-carboxaldehyde", Arch.Appl.Sci.Res.,5(6),227-231(2013).

[29]. A.Abreu, S.J.Alas, H.I.Beltran, R.Santillan, N.Farfan, " Synthesis and characterization of boronates derived from non-symmetric amino-bis-phenols", Journal of Organometallic Chemistry,691,337-348(2006).

[30]. R.M.Silverstein,F.X.Webster," Spectrometric Identification of Organic Compounds", Sixth Edition, John Wiley and Sons Ink., Newyork(1997)

[31]. H.E.Gottlieb, V.Kotlyar, A.Nadelman," NMR Chemical Shift of Common Laboratory Solvents as Trace Impurities", J.Org.Chem., 62(1997).

[32]. G.R.Fulmar, A.J.M.Miller, N.H.Sherden, H.E.Gottleib, A.Nudelman, B.M.Stoltz, J.E.Bercaw, K.I.Goldberg," NMR Chemical Shifts of Trace Impurities: Common Laboratory Solvents, Organics and Gases in Deuterated Solvents Relevant to the Organometallic Chemist", Organometallics, 29, 2176-2179(2010).

[33]. I.Kaya, A.Aydin, " Synthesis, Characterization, Thermal Degradation and Electrical Conductivity of Oligo[2-(Thien-2-ylmethylene)aminophenol] and Oligomer-Metal Complexes", Chinese Journal of Polymer Science, 27,465-477(2009).

[34]. R.A.M.Alaraji," Synthesis And Characterization of New Metal Complexes of Schiff Base Derived From 2-Aminobenzothiazole And Aromatic Aldehydes", MSc.,Thesis, University of Baghdad(2000).

[35]. W.J.Geary,"The use of conductivity measurements in organic solvents for the characterization of coordination compounds", Coordination Chemistry Reviews, 17, 81-122(1971). 